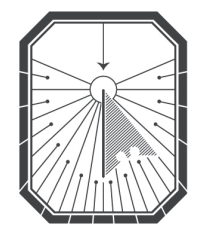

KYIV-MOHYLA

LAW \& POLITICS JOURNAL

KYIV-MOHYLA SCHOLARLY PEER-REVIEWED JOURNALS

Promotion of Renewable Energy in the EU and Ukraine

Author(s): Olha Kaduk

Source: Kyiv-Mohyla Law and Politics Journal 7 (2021): 129-147

Published by: National University of Kyiv-Mohyla Academy

http://kmlpj.ukma.edu.ua/ 


\title{
Promotion of Renewable Energy in the EU and Ukraine
}

\author{
Olha Kaduk \\ National University of Kyiv-Mohyla Academy, Ukraine
}

\begin{abstract}
This article discusses the main reasons for energy transition to RES and examines what is burdening this transition. The main purpose of this article is to overlook the reasons for promotion of renewable energy and main obstacles EU and Ukraine encounter with when heading towards zero-carbon society. The objects of the research were not chosen deliberately: Ukraine is a country which is adopting European aquis communitare and that is why it is extremely important to provide certain comparative research of these formations.
\end{abstract}

Key Words: renewable energy sources, energy transition, climate change, decarbonization Carbon Border Adjustment Mechanism, European Union-Ukraine Association Agreement, Guaranteed Buyer, Energy Charter Treaty, The General Agreement on Tariffs and Trade

\section{(2)}

\section{Introduction}

Affordable and clean energy, sustainable cities and communities, climate action can be found among the Global Goals, adopted by all United Nations Member States in 2015, ${ }^{1}$ under Article 3 of the Paris Agreement. ${ }^{2}$ Currently the promotion of renewable energy is one of the main goals for human beings, because it is the key for a big number of environmental, economic and geopolitical issues resolution.

Nevertheless much concern around this topic remains, which is quite justifiable as promotion of renewable energy keeps facing different challenges and requires very well-weighed policy, ability to anticipate various factors in order to maintain energy security and not to cripple the economy.

$1 \quad$ “Sustainable Development Goals: United Nations Development Programme," UNDP, accessed December 2, 2021, https://www.undp.org/sustainable-development-goals.

2 Anna-Alexandra Marhold, "Externalising Europe's Energy Policy in EU Free Trade Agreements: A Cognitive Dissonance Between Promoting Sustainable Development and Ensuring Security of Supply?" Europe and the World: A Law Review, July 2019, https://doi.org/10.14324/111.444. ewlj.2019.17. 


\section{EU and Ukraine ambitions in energy transition}

EU plays leading role in the climate change politics. ${ }^{3}$ Environmental protection was declared the highest priority by the European Commission. ${ }^{4} \mathrm{EU}$ is the largest issuer of green bonds worldwide ${ }^{5}$ and aspires to become "the first climate-neutral continent" by $205^{\circ} .^{6}$

However, the environmental side of energy issue was not visible at the first stages of the Union evolvement. 7 The initial steps towards promoting RES were taken due to the energy crisis in $197 \mathrm{Os}^{8}$ when Organization of Arab Petroleum Exporting Countries proclaimed an oil embargo. The embargo was imposed on countries, which were supporting Israel during the Yom Kippur War. ${ }^{9}$

After the energy crisis in 1970s Western Europe was extremely concerned about its security of supply. The crisis influenced the shift in EU energy policy and basically impelled EU to diversify its energy sources by implementing RES. Previously renewable energy sources did not play any significant role in the EEC: there used to be no common energy policy either and all energy issues were in the national competence. Thus, two Oil Crises triggered Brussels to seek alternative sources to fossil fuels. Renewables were called for to make countries more independent from external factors. Hence, security of supply was one of the first reasons for developing renewables. As the EU Commissioner for Climate Action and Energy Miguel Arias Cañete hold in his speech at conference in Brussels:

"The key to true energy security lies in renewable energy produced at home here in Europe."10

3 Rüdiger Wurzel, The European Union as a Leader in International Climate Change Politics (London: Routledge, 2011).

4 Ben Aylor, "How an EU Carbon Border Tax Could Jolt World Trade", BCG Global, 30 June 2020, https://www.bcg.com/publications/2020/how-an-eu-carbon-border-tax-could-jolt-worldtrade.

5 "State of the Union Address by President Von Der Leyen at the European Parliament Plenary," European Commission—European Commission, September 16, 2020, https://ec.europa.eu/ commission/presscorner/detail/en/SPEECH_2O_1655.

6 Anna Zygierewicz, "Renewable Energy Directive”, ResearchGate, March 18, 2021, https://www. researchgate.net/publication/350458371_Renewable_Energy_Directive.

$7 \quad$ Elisa Morgera, Introduction to European Environmental Law From an International Environmental Law Perspective (Routledge, 2010), 6, https://papers.ssrn.com/sol3/papers. cfm?abstract_id $=1711372$.

8 Elina Rybnikova, "Economic and Legal Incentives for the Use of Renewable Energy Sources in Ukraine". PhD diss., "Odesa Law Academy," 2018.

9 Charles D. Smith, Palestine and the Arab-Israeli Conflict. (Boston: Bedford/St. Martin’s, 2007), 329 .

10 "True Energy Security Lies in Renewable — Arias Cañete —Energy European Commission," Energy—European Commission, accessed December 2, 2021, https://goo.gl/phlqSY. 
Today the EU policy objective to substitute energy produced from fossil fuels to renewable energy lies in declining EU gas resources, ${ }^{11}$ increasing geopolitical risks ${ }^{12}$ and environmental threats.

The Treaty of Lisbon reflected these issues in legal base and outlined security of supply, competitiveness, and sustainability as major objectives of the EU energy policy.13

Currently EU keeps developing new instruments to combat climate change and setting new targets. According to 2009/28/EC Directive till 2020 share of energy from renewable sources should have been $20 \%$ and, according to Eurostat data, as of 2019

"renewable energy represented $19.7 \%$ of energy consumed in the EU-27, only $0.3 \%$ short of the 2020 target of $20 \% . " 14$

In 2018 EU adopted 2018/2001 Directive, which accounts for the EU Climate and Energy Packages, and is a recast of the 2009/28/EC Directive. It sets a target of $32 \%$ share of energy from renewable sources in EU till 2030.15

Moreover, European Commission developed energy mechanisms, which will not only promote energy transition, but also will allow the economy to recover from the COVID-19 crisis by raising funds for recovery. ${ }^{16}$ Among those instruments are the implementation of the Hydrogen Strategy,17 the EU Strategy for Energy System Integration, ${ }^{18}$ Green Deal and the Carbon Border Adjustment Mechanism (CBAM). ${ }^{19}$

11 Renewable Energy in Europe 2016 Recent Growth and Knock-on Effects (Luxembourg:

Publications Office of the European Union, 2016), https://www.eea.europa.eu/publications/ renewable-energy-in-europe-2016.

12 Renewable Energy in Europe.

13 Treaty on European Union and the Treaty on the Functioning of the European Union, 2012/C 326/o1, December 13, 2007, 194, https://eur-lex.europa.eu/eli/treaty/tfeu_2012/oj.

14 "Renewable Energy Statistics - Statistics Explained," European Commission, accessed December 2, 2021, https://ec.europa.eu/eurostat/statistics-explained/index. php?title=Renewable_energy_statistics.

15 Zygierewicz, Anna. "Renewable Energy Directive." ResearchGate, March 18, 2021, https://www. researchgate.net/publication/350458371_Renewable_Energy_Directive.

16 European Parliament. Proposal for a Regulation of the European Parliament and of the Council Establishing a Carbon Border Adjustment Mechanism, 2021/O214 (COD), July 14, 2O21: 10, https://ec.europa.eu/info/sites/default/files/carbon_border_adjustment_mechanism_o.pdf.

17 "A Hydrogen Strategy for a Climate Neutral Europe," European Commission, accessed December 2, 2021, https://ec.europa.eu/commission/presscorner/detail/en/FS_2O_1296.

18 European Commission. Powering a Climate-neutral Economy: An EU Strategy for Energy System Integration, Communication from the Commission to the European Parliament, the Council, the European Economic and Social Committee and the Committee of the Regions com (2020) 299 final, July 8, 2020, https://ec.europa.eu/energy/sites/ener/files/energy_system_ integration_strategy_.pdf.

19 "Ukrayina i globalna polityka dekarbonizatsiyi [Ukraine and the Global Decarbonization Policy], “ Razumkov Centre, accessed December 2, 2021, https://razumkov.energy/meny/ 
Especially high attention is paid to hydrogen. "The Commission's economic recovery plan "Next Generation EU" highlights hydrogen as an investment priority to boost economic growth and resilience, create local jobs and consolidate the EU's global leadership." 20 The world's leading mining and metallurgical companies have developed carbon-neutral strategies with a focus on the production of low-carbon steel using hydrogen generated by RES facilities. ${ }^{21}$

The novelty pushed by European Parliament resolution of March 10, $2021^{22}$ is Carbon Border Adjustment Mechanism (CBAM) which aims to force trading partners from the countries with less strict legislation on carbon emissions than EU to

"develop production methods with a lower GHG footprint and spur investments in innovation and new technologies." ${ }^{23}$

It is not merely a tax or a customs duty, it is a complex of regulations, which govern importation of products with carbon footprint. CBAM was designed to address carbon leakage and, as a result, to correct the shortcomings of the EU ETS system. Carbon leakage takes place when business entities relocate its production from EU to the countries with "less stringent emissions constraints," ${ }^{24}$ which basically doesn't conform to the EU objectives as in essence occurs an outflow of carbon intensive producers abroad, instead of the implementation of technologies, which would leave less carbon footprint.

Ukrainian energy policy and its decarbonization ambitions are determined largely by Ukrainian European integration course. International treaties today are the main driving forces for developing countries such as Ukraine to approximate their laws to those of the EU and uptake policy which can help them to reach the ambitious targets concerning RES. International treaties generate credible commitments, which have the potential to crystallize international commitments into domestic legislative action. ${ }^{25}$ According to EU Ukraine Association agreement Ukraine has to implement certain

research/ua-energy-transition-research.html.

“A Hydrogen Strategy for a Climate Neutral Europe." European Commission, accessed

December 2, 2021, https://ec.europa.eu/commission/presscorner/detail/en/FS_2O_1296.

21 "Ukraine and the Global Decarbonization Policy."

European Parliament. Towards a WTO-compatible EU Carbon Border Adjustment Mechanism, Resolution 2020/2043(INI), March 10, 2021, https://www.europarl.europa.eu/doceo/document/ TA-9-2021-0071_EN.html.

Report Towards a WTO-compatible EU Carbon Border Adjustment Mechanism. Committee on the Environment, Public Health and Food Safety, accessed December 2, 2021, https://www. europarl.europa.eu/doceo/document/A-9-2021-0o19_EN.html.

24 European Parliament. Proposal for a Regulation of the European Parliament and of the Council Establishing a Carbon Border Adjustment Mechanism, 2021/o214 (COD), July 14, 2021, https:// ec.europa.eu/info/sites/default/files/carbon_border_adjustment_mechanism_o.pdf. 
Directives in the field of energy, energy efficiency and renewable energy sources. After singing the Association agreement, Ukraine has been committed to align its legislation with the European aquis. In particular, Article 338 declares cooperation among others in the sphere of development of renewable energy resources. The specific plan of the cooperation is determined in Annex XXVII to Chapter 1 of Section 5. However, due to the fact that EU acquis is very dynamic, especially in the sphere of renewable energy, Annex XXVII was modified and basically substituted by Annex XXVII-A and Annex XXVII-B. ${ }^{26}$

However, it is worth mentioning that Ukrainian pathway towards carbon neutrality has certain historical background, which proves that this goal was determined not solely by EU decarbonization course. Ukrainian Constitution has very progressive vision as it sets a right to safe environment, which is fundamental for combating climate change and therefore complies with the policy of promotion of renewable sources. This right has been laid down in Ukrainian Constitution since the end of the last century, whereas United Nations only recognized it on October 8, 2021. ${ }^{27}$ In particular, Article $5^{\circ}$ of Ukrainian Constitution provides that

"Everyone shall have the right to an environment that is safe for life and health and to compensation for damages caused by violation of this right." 28

Article 16 establishes that

"Ensuring environmental safety, maintaining ecological balance in the territory of Ukraine, overcoming the aftermath of the Chornobyl catastrophe - the catastrophe of global scale - and preserving the gene pool of the Ukrainian people, shall be the duty of the State."

Moreover, since 1990 by 2018 Ukraine managed to reduce its carbon emissions by $64 \%$. However, this success to a great extent can be ascribed to the dissolution of the Soviet Union and, as a result, the reduction of industrial production. ${ }^{29}$

26 On the position to be taken on behalf of the European Union within the Association Council established by the Association Agreement between the European Union and the European Atomic Energy Community and their Member States, of the one part, and Ukraine, of the other part, as regards the amendment of Annex XXVII to that Agreement, Council Decision (EU) 2019/466, Official Journal of the European Union, March 22, 2019, https://eur-lex.europa.eu/ legal-content/EN/TXT/?uri=uriserv: OJ.L_.2019.080.01.o026.o1.ENG.

"The Right to a Clean and Healthy Environment: 6 Things You Need to Know," UN News, accessed December 2, 2021, https://news.un.org/en/story/2021/10/1103082. 
Green tariff or feed-in tariff was implemented in 2008 and by 2019 the amount of RES was rising steadily. But, on April 25, 2019 the Legislative body in Ukraine has adopted the new law No. 8449-d, which partly cancels FIT and introduces green auctions. As a result, in order to secure feed-in tariff in the first half of 2019 alone, renewable energy facilities with a capacity of more than $1.5 \mathrm{GW}$ were connected to the Ukrainian grid. In the whole of 2018, which has been a record-breaking year so far, numbers were almost half as high. ${ }^{30}$

Ukraine also has commitments under different agreements with international organizations such as Energy Community (EnC) and International Renewable Energy Agency (IRENA), which also gives some benefits and leads Ukraine to the right regulatory decisions.

The Energy Community is a key pillar of the external dimension of the EU energy policy. ${ }^{31}$ The Treaty committed the Contracting Parties to implement the acquis communautaire on energy, environment, competition and renewables. ${ }^{32}$ The Energy Community institutional framework is empowered with many tools to ensure the extension of the EU "energy acquis" to the legal system of the contracting parties. In particular, Moldova and Ukraine are bound by legally binding decisions and nonbinding recommendations of the EnC's institutions and must do its best to ensure their effective application.

As a result of joining IRENA in 2018

"Ukrainian companies that work in the sphere of renewables will receive a number of benefits — such as being able to apply to the Abu Dhabi Fund of Development (ADFD) to receive subsidized credits, to use the other financial instruments available for members and being able to cooperate with other member countries."

Moreover, IRENA predicts that Ukraine has the potential to increase its share of renewables by up to $20-25$ per cent by 2030 . The highest potential is in expanding the

30 "Renewable Energy in Ukraine: Green Auctions Launched," The Legal 50o-The Clients Guide to the best Law firms, top Lawyers, Attorneys, Advocates, Solicitors and Barristers., accessed December 2, 2021, https:/www.legal5oo.com/developments/thought-leadership/renewableenergy-in-ukraine-green-auctions-launched/.

31 Roman Petrov, "Energy Community as a Promoter of the European Union's “Energy Acquis” to Its Neighbourhood," eKMAIR, accessed December 2, 2021, http://ekmair.ukma.edu.ua/ handle/123456789/2276.

32 Davide Berni, "The Institutional Dimension of Energy Market Integration in South-East Europe: Policy-Making of the Energy Community," Academia.edu, April 1, 2014, https://www.academia. edu/6613401/The_Institutional_Dimension_of_Energy_Market_Integration_in_South_East_ Europe_Policy_Making_of_the_Energy_Community. 
country's utilization of biomass because of the abundance of fertile black soil there, further to extensive agricultural and forestry waste too. ${ }^{33}$

\section{Implementation of CBAM in EU and Ukraine}

CBAM is probably the most controversial EU initiative. It was designed to "raise global climate ambition" ${ }^{34}$ by imposing levy on emissions embedded in imports. However, this instrument can potentially violate The General Agreement on Tariffs and Trade (GATT) and consequently could be challenged by EU trading countries. In its Report towards WTO-compatible EU Carbon Border Adjustment Mechanism, prepared by Committee on the Environment, Public Health and Food Safety, the Committee stated that the basis for any CBAM design could be Article I (the principle of most-favored nation treatment), Article III (the national treatment principle) and Article XX (general exceptions). The Committee justifies CBAM using exception prescribed by article XX and insists that this instrument cannot be regarded as protectionism because GATT allows WTO members to implement measures that are necessary to protect human, animal or plant life or health (b), or natural resources (g)." ${ }^{35}$

In its Regulation establishing a Carbon Border Adjustment Mechanism European Parliament emphasizes that it is conscious of the possible negative consequences for implementing CBAM. That is why EU is willing to conduct dialogue and cooperate with third countries "with regard to the implementation of specific elements of the Mechanism." 36

EU is the biggest Ukrainian trading partner: in 2020 the share of goods and services exported from Ukraine to EU constituted $37.8 \%$ from all exports of goods. ${ }^{37}$ The biggest part of Ukrainian export among the scope of products under CBAM includes cast iron and steel. And implementation of CBAM would cost additional 300-90o million euros

33 Agha Bayramov та Yaroslava Marusyk, "Ukraine’s Unfinished Natural Gas and Electricity Reforms: One Step Forward, Two Steps Back." Eurasian Geography and Economics 6o, No. 1 (January 2019) https://doi.org/10.1080/15387216.2019.1593210.

"MEPs: Put a Carbon Price on Certain EU Imports to Raise Global Climate Ambition | News | European Parliament," European Parliament, March 10, 2021, https://www.europarl.europa.eu/ news/en/press-room/20210304IPR99208/meps-put-a-carbon-price-on-certain-eu-imports-toraise-global-climate-ambition.

Report Towards a WTO-compatible EU Carbon Border Adjustment Mechanism. Committee on the Environment, Public Health and Food Safety, accessed December 2, 2021, https://www. europarl.europa.eu/doceo/document/A-9-2021-0o19_EN.html.

36 European Parliament. "Proposal for a Regulation."

37 Influence of Carbon Mechanism Import Adjustment (CBAM) for Ukraine's Trade With the EU (Resource and Analytical Center "Society and Environment", November 2021), https://www. rac.org.ua/uploads/content/624/files/cbamukraineua.pdf?fbclid=IwARoOCfWRil4XbjucSqWYI o6Py-jjNwTgKA3hJAxS6497MFQijr3hdTv9TbE. 
per year. ${ }^{38}$ In order to eliminate negative impact of CBAM on Ukrainian producers, Ukraine should resorted to subsidizing strategic enterprises, gradual decarbonization of the entire chain of production and transportation of goods, and connect to the European quota trading system EU ETS. ${ }^{39}$ Decarbonization could be reached primarily by implementation of renewable energy sources and introduction of new technologies, such as green hydrogen.

\section{The main challenges Ukraine encounters in its pathway to carbon neutrality}

An annual Implementation Report prepared by Energy Community Secretariat on November 1, 2021 laid down that Ukrainian implementation status for Renewable energy is described as "moderately advanced." 40 The shortcomings defined by Secretariat comprise renewable energy sector instability and certain design flaws, the low status of implementation in the transport sector (share of RES in transport constitutes 3.1\%), non-implementation of a functional market-based support scheme and the absence of an electronic system for guarantees of origin. ${ }^{41}$

However, approximation Ukrainian legislation in energy sector and notably development of RES in Ukraine cannot be productive against a backdrop of Guaranteed Buyer failure to settle its payments. The Guaranteed buyer is, in particular, authorized to buy energy from the renewable energy producers by paying them the high-priced feedin tariff, and sell it to energy suppliers. In the Act "On Electricity Market" it is prescribed that payment received for service of increasing the share of electricity production, provided to energy transmission operator Ukrenergo, is a source of payment to the RES producers. ${ }^{42}$ Hence, the compensation of the Guaranteed Buyer's debt is placed on Ukrenergo. ${ }^{43}$ Ukrenergo is unable to pay the debt due to the existence of crosssubsidizing system, which implies that a certain category of consumers buys energy for a fixed price that is less than the market price. ${ }^{44}$ This discrepancy between fixed price and market price is subsidized by business. The deficit might be covered only by taking a set of multi-vector measures, in particular by implementing initiatives

38 Influence of Carbon Mechanism Import Adjustment.

39 "Ukraine and the Global Decarbonization Policy."

40 Annual Implementation Report (Vienna: Energy Community Secretariat, November 2021).

41 Annual Implementation Report (Vienna: Energy Community Secretariat, November 2021).

42 Zakon Ukrayiny "Pro rynok elektrychnoyi enerhiyi [Law of Ukraine "On Electricity Market"], of November 9, 2017, https://zakon.rada.gov.ua/rada/show/2019-19\#Text.

New Electricity Market (Razumkov centre, 2020), accessed December 26, 2021, https://fru.ua/ images/doc/analitics/Novij_rinok_el.en_2020.pdf.

"The Situation With RES-generation Lawsuits May Be Critical for Us and for the Energy System -Interview with Serhiy Petrokovets, Director of the Guaranteed Buyer," Interfax-Ukraine, June 3 o 2021, https://ua.interfax.com.ua/news/interview/75277o.html. 
to support the RES sector and by raising the transmission system operator's tariff. 45 Some measures have already been taken, in particular, Green and Sustainability-linked bonds were issued by Ukrenergo for a USD 825 million size. ${ }^{46}$ Furthermore, in the framework of mediation between the Ministry of Energy of Ukraine and some major renewable energy associations of Ukraine ${ }^{47}$ the Memorandum of Understanding has been adopted. The parties reached a conclusion that RES producers will be able to sell energy for market price directly on the bilateral contracts market, the day-ahead market; the intraday market; and the balancing market, bypassing the Guaranteed Buyer. The difference between the feed-in tariff price and the estimated market price" will then be paid by the Guaranteed Buyer. ${ }^{48}$ The above-mentioned instrument is called the Feed-in Premium and it is widely used in EU. However, there is only a draft law on Feed-in Premium and it is not yet implemented.

In respect of market-based support scheme, the auction system was introduced in 2019 However, the quotas and schedule for auctions have not been approved, delaying the launch of auctions initially due in 2020.49 And as a result, auctions envisaged as a new support scheme for RES are yet to be implemented..$^{50}$

Whilst on March 23, 2021 first international arbitration against Ukraine under the Energy Charter Treaty was launched. Modus operates 3 solar power plants in Ukraine and received feed-in tariff in 2019. ${ }^{51}$ However, from August 1, 2020, the amount of tariff, which was guaranteed until the end of 2029 , was reduced by $15 \%$. The plaintiff alleges a violation of Article $10 \S 1$ of the Energy Charter Treaty and estimates its losses at EUR 11.5 million.. ${ }^{2}$

45 "Guidelines for the Development of Alternative Energy in Ukraine Until 203०," Razumkov centre, accessed December 2, 2021, https://razumkov.energy/meny/research/research-strategyres-203o.html.

46 "Ukrenergo Has Successfully Priced a Debut 5-Year Green and Sustainability-Linked Eurobond," Ukrenergo, November 3, 2021, https://ua.energy/media-2/ukrenergo-has-successfully-priced-adebut-5-year-green-and-sustainability-linked-eurobond/.

"Ukraine Considers Feed-in-Premiums to Further Support Renewable Energy Projects," CMS

LAW-NOW, September 13, 2021, https://www.cms-lawnow.com/ealerts/2021/og/ukraineconsiders-feed-in-premiums-to-further-support-renewable-energy-projects.

48 Ukraine Considers.

49 Svitlana Teush, "Quotas and Schedule of the First Renewable Energy Auctions in Ukraine Presented by the Ministry of Energy — Energy and Natural Resources — Ukraine," Welcome to Mondaq, December 8, 2020, accesed December 26, 2021, https://www.mondaq.com/ renewables/10136o8/quotas-and-schedule-of-the-first-renewable-energy-auctions-in-ukrainepresented-by-the-ministry-of-energy. Annual Implementation Report (Vienna: Energy Community Secretariat, November 2021).

$5^{1} \quad$ "First International Arbitration Launched by Renewable Investor Against Ukraine," Imepower, accessed December 2, 2021, https://www.imepower.com/en/first-international-arbitrationlaunched-by-renewable-investor-against-ukraine/.

52 Renewable trust," Legal Practice, 45-46 (1246-1247) (2021): 20, https://pravo.ua/ articles/vidnovliuvana-dovira/. 
The EU countries also encountered claims against them on the basis of failure to meet its commitments due to the high-priced feed-tariffs. The examples of the drastic negative consequences of pro-renewable energy policy, which resulted in several investment treaty arbitrations against some of the EU members: Spain, Czech Republic and Italy. In these countries the authorities failed to anticipate the global financial recession and the decline in the cost of solar panels. 53 "FITs as clean energy strategies were ambitious and did not foresee the financial and technological challenges the renewable industry represents. As consequence, national schemes went beyond the financial capabilities of some MS and FITs had to be withdrawn from foreign investors." ${ }^{4}$

\section{Energy Charter Treaty and EU pathway to carbon neutrality}

With the purpose to diversify its energy transfers and consequently maintain its energy security EU entered into ECT. Geopolitical risks and basically the importance to maintain energy security was among the main reasons to adopt the Energy Charter Treaty in 1994 (came into effect in 1998). Basically, it was adopted to develop cooperation in energy between East and West. ${ }^{55}$

However, most of the provisions of Energy Charter have not been revised since the 199os. This created problems especially in the area of investment protection, which no longer correspond to modern standards. ${ }^{6}$ Unfortunately, ECT doesn't reflect and even hamper the energy transition as it does not differentiate between the investments made in different energy sources: fossil fuels and renewable energy. ${ }^{57}$ That is why the Energy Charter Conference, which took place on October 6, 2019 has revealed that

53 Daniel Behn, Ole Kristian Fauchald, Laura Letourneau-Tremblay "Promoting Renewable Energy in the EU: Shifting Trends in Member State Policy Space," SSRN Electronic Journal (January 2015): $217-243$.

54 United Nations Environment Programme (UNEP), The Global Financial Crisis and its Impact on Renewable Energy Finance, accessed December 26, 2021 http://www.unep.org/pdf/dtie/ Study_Financial_Crisis_impact_on_RE.pdf; Julien Chaisse, "Renewables Re-Energized? The Internationalization of Green Energy Investment Rules and Disputes," Journal of World Energy Law \& Business 9, no. 4 (July 2016):169, https://doi.org/10.1093/jwelb/jwwo18.

Bai Zhonghong, Trade Development Through Harmonization of Commercial Law, accessed December 26, 2021, https://www.wgtn.ac.nz/law/research/publications/about-nzacl/ publications/special-issues/hors-serie-volume-xvi,-2013/Bai.pdf.

"Council Adopts Negotiation Directives for Modernisation of Energy Charter Treaty," Council of the European Union, July 15, 2019, https://www.consilium.europa.eu/en/press/pressreleases/2019/o7/15/council-adopts-negotiation-directives-for-modernisation-of-energycharter-treaty/. Elena Cima, “The EU and the Modernisation of the Energy Charter Treaty: What Could It Mean for Climate Action?" April 2020, Video, https://www.youtube.com/watch?v=jRHC4BhkrU\&amp; ab_channel=EuropeanandInternationalEnvironmentalLaw. 
"The Modernized ECT should reflect climate change and clean energy transition goals and contribute to the achievement of the objectives of the Paris Agreement." ${ }^{58}$

ECT covers the environment protection issues and at first sight it might seems that the ECT articles such as Article 19 on Environmental aspects or Article 24 Exceptions take into consideration environmental issues. However environmental protection is rather declaratory in the ECT Article 24 ECT allows, among others, an exception necessary to

"protect human, animal or plant life or health,"

but its subject area is also strictly limited. Firstly, it does not apply to Part III of the ECT dealing with investment protection and the qualifying criteria for the application of Article 24 ECTs to a large extent dilute its practical effect.59

Under ECT a signatory state must extend to another party that is a beneficiary of the clause the most-favorable treatment that it would have granted to a third party. ${ }^{60}$ Mostfavored nation (MFN) is now a both common and controversial clause in investment treaties. ${ }^{61}$ It allows investors to settle disputes with respect to alleged discriminatory treatment. Tribunals were quite reluctant to accept the arguments of the respondent state that there was actually no discrimination precisely because the investors were not in like circumstances because of their different environmental impact. Arbitral tribunals were not really responsive to these arguments mostly because they relied on the notion and the interpretation likeness as it had been developed in international trade law. Likeness is an element to find possible discrimination between products. The environmental footprint of the product, in particular of the process or production method of the product is not taken into account in the definition of likeness. ${ }^{62}$

ECT limits the right to regulate and what is more doesn't even refer to the right to regulate and this makes it very unbalanced in favor of the investors. That is why the other message of the mentioned Conference was that

"The objective of the Modernized ECT should be to facilitate investment in the energy sector in a sustainable way between the

$5^{8}$ Energy Charter Secretariat. Decision of the Energy Charter Conference, CCDEC 2019, October 6, 2019, https://www.energycharter.org/fileadmin/DocumentsMedia/CCDECS/2019/ CCDEC2019o8.pdf.

59 Ivan Gudkov, “Greening” of Economic Relations in Law (On the Example of the Energy Industry)," Journal of Foreign Legislation and Comparative Law 5 (2020).

6o Suzy H. Nikièma, “The Most-Favoured Nation Clause in Investment Treaties," IISD Best Practices Series: The Most-Favoured-Nation Clause in Investment Treaties, 2017, https://www.iisd.org/ system/files/publications/mfn-most-favoured-nation-clause-best-practices-en.pdf.

61 Nikièma, "The Most-Favoured Nation Clause in Investment Treaties."

62 Cima, "The EU and the Modernisation." 
ECT Contracting Parties by creating a coherent and up-to- date legally binding framework that provides for legal certainty and ensures a high level of investment protection while respecting the ECT Contracting Parties' right to regulate." 63

It gives corporations enormous power to sue states for billions. For example, if a government decides to stop new oil, gas or coal projects. The examples of the drastic negative consequences of pro-renewable energy policy, which resulted in several investment treaty arbitrations against some of the EU members: Spain, Czech Republic and Italy. In these countries the authorities failed to anticipate the global financial recession and the decline in the cost of solar panels. ${ }^{64}$

"FITs as clean energy strategies were ambitious and did not foresee the financial and technological challenges the renewable industry represents. As consequence, national schemes went beyond the financial capabilities of some MS and FITs had to be withdrawn from foreign investors. ${ }^{6 "}$

The most relevant cases concerning burdening energy transition include:

- Rockhopper v. Italy ICSID Case No. ARB/17/14

- Vattenfall v. Germany (II) ICSID Case No. ARB/12/12

- EVN AG v. Republic of Bulgaria ICSID Case No. ARB/13/17

From among problems towards burdening the energy transition these cases clearly demonstrate contradictions between EU law and the ECT. E.g., in the case Rockhopperv. Italy ICSID Case No. ARB/17/14. In this case Respondent refers to three specific Articles of the ECT - Articles 1, 16 and 25 - to further its argument that the terms of the ECT recognizes the EU as a unified legal system whose provisions prevail over the ECT itself. In support of this argument, the Respondent relies on Opinion 1/o9 of the CJEU of March 8, 2011 ("Opinion 1/o9"), which addressed the creation of a unified patent litigation system for resolving disputes between private parties. ${ }^{66}$ In the case Vattenfall v. Germany (II) ICSID Case No. ARB/12/12 claim appeared due to Germany's enactment of legislation to phase out nuclear power plants in the country by 2022 . Vattenfall argues that Hamburg's environmental rules amounted to an expropriation and a violation of Germany's obligation to afford foreign investors "fair and equitable treatment." 67

63 Energy Charter Secretariat. "Decision of the Energy Charter Conference."

64 Behn, "Promoting Renewable Energy in the EU."

65 UN, "The Global Financial Crisis"; Chaisse, "Renewables Re-Energized?"

66 Rockhopper Italia S. P.A., Rockhopper Mediterranean LTD, and Rockhopper Exploration PLC and Italian Republic, ICSID, June 26, 2019, ARB/17/14, accessed December 26, 2021, https:// www.italaw.com/sites/default/files/case-documents/italawıo646_o.pdf.

67 "Corporate Attacks: Health Case Study: Coal-Fired Electric Plant," accessed December 2, 2021, http://media.wix.com/ugd/7co358_f3446f51732e46c99d5b55d7bf8a654c.pdf. 
This case also clearly demonstrates the contradictions between EU law and ECT as in 2017 the European Court of Justice ruled that Germany breached EU environmental law when it authorized Vattenfall's plant. ${ }^{68}$ In the case EVN AG v. Republic of Bulgaria ICSID Case No. $A R B / 13 / 17$ the investor issued legal proceeding against Bulgaria because it reduced energy prices, which skyrocketed partly due to a surge in expensive green energy. 69

Eventually, the ECT probably does burden the EU energy transition because it is very unbalanced in favor of the investor and basically hugely limits countries' right to regulate.

\section{Conclusion}

Renewable energy sources, which started evolving not in the framework of climate change combating policy, but in the framework of energy security, today is called for mainly to resolve the first issue. As a leader in combating climate change, EU pursues ambitious targets especially in promoting renewable energy sources. It prompts new technologies such as green hydrogen and develops new climate measures, such as Carbon Border Adjustment Mechanism (CBAM) to reach its targets. Basically, CBAM reflects an EU ambition to extrapolate its climate change policy abroad to force other countries to set and reach climate targets. As long as it is an international problem, it should be a matter of concern worldwide. To serve that purpose EU designed CBAM, and by using this instrument is going to levy additional payments on the emissions embedded in specific products imported to EU. This will address the problem of carbon leakage and incentivize EU trade partners to support renewable energy producers. However, there is much concern about the compliance of CBAM with the General Agreement on Tariffs and Trade, which should be addressed till 2026 when CBAM becomes operational.

Since EU is the main Ukrainian trade partner, it is important to revise its policy towards RES in order to mitigate the consequences of implementing CBAM. Association agreement does not comprise all initiatives regarding Green Deal and decarbonization, but in the framework of the negotiations between EU and Ukraine on EU green policy, which might have a great impact on Ukrainian business, which is importing or exporting EU.

Today "Ukraine shares the EU's climate ambitions and has expressed its desire to contribute to the achievement of Europe's climate neutrality goals." ${ }^{70}$ Ukrainian

68 European Commission, v. Federal Republic of Germany, European Court of Justice, April 26, 2017, C-142/16.

69 Reuters Staff, "EVN Prepares Legal Action on Bulgarian Electricity Dispute," U.S., March 19, 2013, accessed December 26, 2021, https://www.reuters.com/article/austria-evn-bulgaria/evnprepares-legal-action-on-bulgarian-electricity-dispute-idUSL6NoCB6DU2O130319.

70 Report on Implementation of the Association Agreement Between Ukraine and the European Union 2015-2020 (Government Office for Coordination of European and Euro-Atlantic 
commitment to carbon reductions is set out in the "Concept of State Climate Change Policy Implementation until 2030."

The implementation status for Renewable energy is described by Energy Community as "moderately advanced." 71 The most burdensome factor is the producers' underpayment because of the cross-subsidizing system and as a result failure of the Guaranteed Buyer to settle its payments. However, Ukraine managed to solve this problem partly by issuing Eurobonds, by conducting negotiations and signing Memorandum with the producers and other measures.

Another challenge in its pathway to carbon-neutrality is the Energy Charter Treaty, which does not differentiate between the investments made in different energy sources and need to be aligned with modern policy on climate change.

\section{Bibliography}

"A Hydrogen Strategy for a Climate Neutral Europe." European Commission. Accessed December 2, 2021. https://ec.europa.eu/commission/presscorner/detail/en/ FS_2O_1296.

"Corporate Attacks: Health Case Study: Coal-Fired Electric Plant." Accessed December

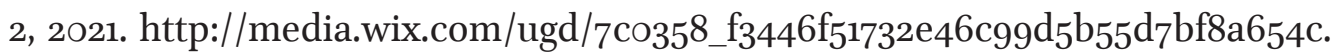
pdf.

"Council Adopts Negotiation Directives for Modernisation of Energy Charter Treaty." Council of the European Union. July 15, 2019. https://www.consilium.europa.eu/ en/press/press-releases/2019/o7/15/council-adopts-negotiation-directives-formodernisation-of-energy-charter-treaty/.

"First International Arbitration Launched by Renewable Investor Against Ukraine." Imepower. Accessed December 2, 2021. https://www.imepower.com/en/firstinternational-arbitration-launched-by-renewable-investor-against-ukraine/.

"Guidelines for the Development of Alternative Energy in Ukraine Until 2030." Razumkov centre. Accessed December 2, 2021. https://razumkov.energy/meny/ research/research-strategy-res-203o.html.html.

"MEPs: Put a Carbon Price on Certain EU Imports to Raise Global Climate Ambition | News | European Parliament." European Parliament. March 10, 2021. Accessed December 26, 2021. https://www.europarl.europa.eu/news/en/pressroom/20210304IPR99208/meps-put-a-carbon-price-on-certain-eu-imports-toraise-global-climate-ambition.

"Renewable Energy in Ukraine: Green Auctions Launched." The Legal 5oo-The Clients Guide to the Best Law firms, top Lawyers, Attorneys, Advocates, Solicitors and Barristers. Accessed December 2, 2021. https://www.legal5oo.com/developments/ thought-leadership/renewable-energy-in-ukraine-green-auctions-launched/.

Integration), accessed December 2, 2021, https://eu-ua.kmu.gov.ua/sites/default/files/inline/ files/aa_implementation_report_2015-202O_eng_final.pdf.

71 Annual Implementation Report (Vienna: Energy Community Secretariat, November 2021). 
"Renewable Energy Statistics — Statistics Explained." European Commission. Accessed December 2, 2021. https://ec.europa.eu/eurostat/statistics-explained/index. php?title=Renewable_energy_statistics.

"State of the Union Address by President Von der Leyen at the European Parliament Plenary." European Commission-European Commission, September 16, 2020. Accessed December 26, 2021. https://ec.europa.eu/commission/presscorner/ detail/en/SPEECH_2O_1655.

“The Right to a Clean and Healthy Environment: 6 Things You Need to Know." UN News. Accessed December 2, 2021. https://news.un.org/en/story/2021/10/1103082.

"The Situation With RES-generation Lawsuits May Be Critical for Us and for the Energy System -Interview with Serhiy Petrokovets, Director of the Guaranteed Buyer." Interfax-Ukraine, June 30, 2021. Accessed December 26, 2021. https://ua.interfax. com.ua/news/interview/75277o.html.

"True Energy Security Lies in Renewable-Arias Cañete-Energy European Commission." Energy - European Commission. Accessed December 2, 2021. https://goo.gl/phlqSY.

"Ukraine and the Global Policy of Decarbonisation." Razumkov centre. Accessed December 2, 2021. https://razumkov.energy/meny/research/ua-energy-transitionresearch.html.

"Ukraine Considers Feed-in-Premiums to Further Support Renewable Energy Projects." CMS LAW-NOW, September 13, 2021. Accessed December 26, 2021. https://www. cms-lawnow.com/ealerts/2021/og/ukraine-considers-feed-in-premiums-tofurther-support-renewable-energy-projects.

"Ukrenergo Has Successfully Priced a Debut 5-Year Green and Sustainability-Linked Eurobond." Ukrenergo. November 3, 2021. https://ua.energy/media-2/ukrenergohas-successfully-priced-a-debut-5-year-green-and-sustainability-linkedeurobond/.

"Vidnovliuvana dovira [Renewable trust]" Yurydychna praktyka 45-46 (1246-1247) (2021). Accessed December 26, 2021. https://pravo.ua/articles/vidnovliuvanadovira/.

"Ukraine and Global Decarbonization Policy." Razumkov centre. Accessed December 2, 2021. https://razumkov.energy/meny/research/ua-energy-transition-research. html.

“Sustainable Development Goals: United Nations Development Programme." UNDP. Accessed December 2, 2021. https://www.undp.org/sustainable-developmentgoals.

Annual Implementation Report. Vienna: Energy Community Secretariat, November 2021.

Constitution of Ukraine. 28 June 1996.

Treaty on European Union and the Treaty on the Functioning of the European Union. 2012/C 326/o1. December 13, 2007. https://eur-lex.europa.eu/eli/treaty/tfeu_2012/oj. 
Zakon Ukrayiny "Pro rynok elektrychnoyi energiyi [Law od Ukraine "On Electricity Market]." of November 9, 2017. https://zakon.rada.gov.ua/rada/show/2019-19\#Text. Aylor, Ben, Marc Gilbert, Nikolaus Lang, Michael McAdoo, Johan Öberg, Cornelius Pieper, Bas Sudmeijer та Nicole Voigt. "How an EU Carbon Border Tax Could Jolt World Trade." BCG Global. June 30, 2020. Accessed December 26, 2021. https:// www.bcg.com/publications/2020/how-an-eu-carbon-border-tax-could-joltworld-trade.

Bayramov, Agha, та Yaroslava Marusyk. "Ukraine’s Unfinished Natural Gas and Electricity Reforms: One Step Forward, Two Steps Back." Eurasian Geography and Economics 6o, no. 1 (January 2019): 73-96. https://doi.org/10.108o/15387216.2019. 1593210.

Behn, Daniel, Ole Kristian Fauchald та Laura Letourneau-Tremblay. "Promoting Renewable Energy in the EU: Shifting Trends in Member State Policy Space." SSRN Electronic Journal, 2015. https://doi.org/10.2139/ssrn.2704333.

Berni, Davide. "The Institutional Dimension of Energy Market Integration in South-East Europe: Policy-Making of the Energy Community." Academia.edu. April 1, 2014. https://www.academia.edu/6613401/The_Institutional_Dimension_of_Energy_ Market_Integration_in_South_East_Europe_Policy_Making_of_the_Energy_ Community.

Chaisse, Julien. "Renewables Re-Energized? The Internationalization of Green Energy Investment Rules and Disputes." Journal of World Energy Law \& Business 9 no. 4 (July 2016): 269-81. https://doi.org/10.1093/jwelb/jwwo18.

Cima, Elena. "The EU and the Modernisation of the Energy Charter Treaty: What Could It Mean for Climate Action?" (April 2020). Video, 11:48. Accessed December 26, 2021. https://www.youtube.com/watch?v=j-RHC4BhkrU\&amp; ab_channel=EuropeanandInternationalEnvironmentalLaw.

Davide, Berni "The Institutional Dimension of Energy Market Integration in SouthEast Europe: Policy-Making of the Energy Community." Academia.edu. April 1, 2014. Accessed December 26, 2021. https://www.academia.edu/6613401/The Institutional_Dimension_of_Energy_Market_Integration_in_South_East_Europe Policy_Making_of_the_Energy_Community.

Decision of the Energy Charter Conference. CCDEC 2019. October 6, 2019. Accessed December 26, 2021. https://www.energycharter.org/fileadmin/DocumentsMedia/ CCDECS/2019/CCDEC2019o8.pdf.

Energy Charter Secretariat. Decision of the Energy Charter Conference. CCDEC 2019. October 6, 2019. Accessed December 26, 2021. https://www.energycharter.org/ fileadmin/DocumentsMedia/CCDECS/2019/CCDEC2019o8.pdf.

European Commission, v. Federal Republic of Germany. European Court of Justice. April 24, 2017. C-142/16.

European Commission. Powering a climate-neutral economy: An EU Strategy for Energy System Integration. Communication from the Commission to the European Parliament, the Council, the European Economic and Social Committee and the Committee of the Regions COM (2020) 299 final. July 8, 2020. Accessed December 
26, 2021. https://ec.europa.eu/energy/sites/ener/files/energy_system_integration_ strategy_.pdf.

European Parliament. Proposal for a Regulation of the European Parliament and the Council Establishing a Carbon Border Adjustment Mechanism. 2021/0214 (COD). July 14, 2021. Accessed December 26, 2021. https://ec.europa.eu/info/sites/default/ files/carbon_border_adjustment_mechanism_o.pdf.

European Parliament. Towards a WTO-compatible EU carbon border adjustment mechanism. Resolution 2020/2043(INI). March 10, 2021. Accessed December 26, 2021. https://www.europarl.europa.eu/doceo/document/TA-9-2021-0o71_ EN.html.

Gudkov, Ivan. “'Greening” of Economic Relations in Law (On the Example of the Energy Industry)." Journal of Foreign Legislation and Comparative Law 5 (2020):124-41.

Influence of Carbon Mechanism Import Adjustment (CBAM) for Ukraine's Trade With the $E U$. Resource and Analytical Center "Society and Environment," November 2021. Accessed December 26, 2021. https://www.rac.org.ua/uploads/content/624/files/ cbamukraineua.pdf?fbclid=IwARoOCfWRıl4XbjucSqWYIo6Py-jjNwTgKA3hJAx S6497MFQijrshdTvgTbE.

Marhold, Anna-Alexandra. “Externalising Europe's Energy Policy in EU Free Trade Agreements: A Cognitive Dissonance Between Promoting Sustainable Development and Ensuring Security of Supply?" Europe and the World: A Law Review, July 2019. https://doi.org/10.14324/111.444.ewlj.2019.17.

Morgera, Elisa. Introduction to European Environmental Law from an International Environmental Law Perspective. Routledge, 2010. Accessed December 26, 2021. https://papers.ssrn.com/sol3/papers.cfm?abstract_id=1711372.

New Electricity Market. Razumkov centre, 2020. Accessed December 26, 2021. https:// fru.ua/images/doc/analitics/Novij_rinok_el.en_202O.pdf.

Nikièma, Suzy H. "The Most-Favoured Nation Clause in Investment Treaties". IISD Best Practices Series: The Most-Favoured-Nation Clause in Investment Treaties, 201725. Accessed December 26, 2021. https://www.iisd.org/system/files/publications/mfnmost-favoured-nation-clause-best-practices-en.pdf.

On the position to be taken on behalf of the European Union within the Association Council established by the Association Agreement between the European Union and the European Atomic Energy Community and their Member States, of the one part, and Ukraine, of the other part, as regards the amendment of Annex XXVII to that Agreement. COUNCIL DECISION (EU) 2019/466. March 18, 2019. Official Journal of the European Union, March 22, 2019. Accessed December 26, 2021. https://eurlex.europa.eu/legal-content/EN/TXT/?uri=uriserv: OJ.L_.2019.080.01.0026.o1.ENG.

Petrov, Roman. "Energy Community as a Promoter of the European Union's "Energy Acquis" to Its Neighbourhood: [Preprint]." eKMAIR. Accessed December 2, 2021. http://ekmair.ukma.edu.ua/handle/123456789/2276. 
Renewable Energy in Europe 2016 Recent Growth and Knock-on Effects. Luxembourg: Publications Office of the European Union, 2016. Accessed December 26, 2021. https://www.eea.europa.eu/publications/renewable-energy-in-europe-2016.

Report on Implementation of the Association Agreement Between Ukraine and the European Union 2015-202O. Government Office for Coordination of European and Euro-Atlantic Integration. Accessed December 2, 2021. https://eu-ua.kmu.gov.ua/ sites/default/files/inline/files/aa_implementation_report_2015-202O_eng_final. pdf.

Report Towards a WTO-compatible EUCarbon Border Adjustment Mechanism. Committee on the Environment, Public Health and Food Safety. Accessed December 2, 2021. https://www.europarl.europa.eu/doceo/document/A-9-2021-oo19_EN.html.

Rockhopper Italia S. P.A., Rockhopper Mediterranean LTD, and Rockhopper Exploration PLC and Italian Republic. ICSID. June 26, 2019. ARB/17/14. Accessed December 26, 2021. https://www.italaw.com/sites/default/files/case-documents/italaw10646_o. pdf.

Rybnikova, Elina. "Economic and Legal Incentives for the Use of Renewable Energy Sources in Ukraine." (PhD diss., "Odesa Law Academy," 2018).

Smith, Charles D. Palestine and the Arab-Israeli Conflict. Boston: Bedford/St. Martin's, 2007.

Staff, Reuters. "EVN Prepares Legal Action on Bulgarian Electricity Dispute.” U.S., March 19, 2013. Accessed December 26, 2021. https://www.reuters.com/article/ austria-evn-bulgaria/evn-prepares-legal-action-on-bulgarian-electricity-disputeidUSL6NoCB6DU20130319.

Teush, Svitlana. "Quotas and Schedule of the First Renewable Energy Auctions in Ukraine Presented by the Ministry of Energy — Energy and Natural Resources Ukraine." Welcome to Mondaq, December 8, 2020. Accessed December 26, 2021. https://www.mondaq.com/renewables/10136o8/quotas-and-schedule-of-the-firstrenewable-energy-auctions-in-ukraine-presented-by-the-ministry-of-energy.

The Global Financial Crisis and its Impact on Renewable Energy Finance. United Nations Environment Programme (UNEP), April 2009.

Wurzel, Rüdiger. The European Union as a Leader in International Climate Change Politics. London: Routledge, 2011.

Zhonghong, Bai. Trade Development Through Harmonization of Commercial Law. Accessed December 26, 2021. https://www.wgtn.ac.nz/law/research/publications/ about-nzacl/publications/special-issues/hors-serie-volume-xvi,-2013/Bai.pdf.

Zygierewicz, Anna. "Renewable Energy Directive". ResearchGate, March 18, 2021. Accessed December 26, 2021. https://www.researchgate.net/publication/350458371_ Renewable_Energy_Directive.

Olha Kaduk is a graduate student at the Faculty of Law, National University of KyivMohyla Academy. 


\title{
Популяризація Відновлюваної Енергетики в ЄС та Україні
}

\section{Ольга Кадук}

Національний університет “Києво-Могилянська академія”, Україна

\begin{abstract}
Анотація
Ця стаття присвячена огляду питань про основні причини переходу енергетики на відновлювані джерела енергії та досліджує проблемні питання цього переходу. Основна мета статті-зробити огляд підстав популяризації відновлюваної енергетики, а також основних викликів, з якими стикаються Україна та ЄС на шляху до суспільства без вуглецевих викидів. Вибір об'єктів дослідження спричинений тим, що Україна є державою, яка сприйняла європейське aquis communitare, що зумовлює необхідність здійснення цього порівняльного дослідження.
\end{abstract}

Ключові слова: джерела відновлюваної енергії, енергетичний транзит, зміни клімату, Механізм транскордонного вуглецевого регулювання, Угода про асоціацією між Україною та ЄС, гарантований покупець, Енергетична Хартія, Генеральна угода про тарифи і торгівлю 